\title{
Trends in characterizing single cell's stiffness properties
}

\author{
Ida Laila Ahmad ${ }^{1}$ and Mohd Ridzuan Ahmad ${ }^{2^{*}}$
}

\begin{abstract}
Biophysical properties of living cells such as mechanical and chemical have been proven to play important roles in regulations of various biological activities including disease progression both at the cellular and molecular levels. In the past decades, a number of research tools have been developed to provide better understanding towards cell's biophysical states. This growing interest was supported by the emergence of researches focusing on single cell analysis (SCA) which serves as a platform enabling various experimentation works to be carried out. In this context, various techniques have been developed for single cell's mechanical characterization to improve robustness, accuracy and operational flexibility. The generic solution varies from traditional approach, microelectromechanical system (MEMS) and microfluidic. This paper presents a review of progress and developments in the field of single cell mechanical properties specifically discussing on stiffness characterizations. An analytical comparison of the reviewed solutions is presented, and the advantages and disadvantages of different techniques are compared.
\end{abstract}

Keywords: Biophysical properties; Single cell analysis (SCA); Traditional approach; Microelectromechanical system (MEMS); Microfluidic; Stiffness characterization

\section{Review}

Living cells are unique; it can sense mechanical stimuli and convert them into biological response [1]. Similarly, biological and biochemical signals play vital role in translating the cell's abilities to sense, generate and endure with mechanical forces. Studies into mechanics of single cells have been rapidly evolved during past decades with significant implications towards human health. Cells experience mechanical deformation due to external forces and geometric restrictions as any other engineering material plus mechanical forces are indispensable to living cells [2]. Any alteration to such forces is likely to cause a disruption towards functions, thereby producing a diseased state or sickle cell. For instance, higher possibility of heart failure is due to loss of contractility of heart muscle cells [3]. In fact, severe stretching of the axon of neural cells during traumatic brain injury may cause cell death [4]. The deformation of soft muscle cells in compliance of blood vessel wall is crucial for hypertension. Likewise, parasitized red blood cells (RBC) caused by malaria are known to

\footnotetext{
* Correspondence: ridzuan@fke.utm.my

${ }^{2}$ Faculty of Electrical Engineering, Universiti Teknologi Malaysia, 81310 UTM

Skudai, Johor, Malaysia

Full list of author information is available at the end of the article
}

deform and becoming stiffer which prevent them to transport oxygen efficiently [5]. When erythrocyte stiffens causing vessel occlusion, patients might suffer from coma and this may lead to death. Moreover, the pathology of cancer progress and metastatic diseases have been studied previously showing the changes in morphology; size, adhesion and deformability occurred for transition from normal to malignant cells [6]. On the whole, cell's mechanical properties represent the physical structure of living cells and have been proved to be effective as label-free biomarkers for detecting abnormalities in diseased cells [7].

\section{Single cell analysis}

Earlier, the investigations towards cells were made in population. Tacit assumptions made such that all cells are identical and focussing only on global understanding of cellular response [1]. In reality, even cells within a same population and with similar functions respond asynchronously thus making particular studies on kinetics and dynamics of cell population is impossible. Despite that, most of the techniques generally suffer from several limitations due to averaging measured parameters, lack of coherence due to cell heterogeneity and it also conceal the importance of subpopulation existence. 
Growing interests towards single cell analysis (SCA) blossomed and foreseeing the emergence of many SCA research clusters all over the world. Research done in various areas including single cell genomics, single cell measurements on secreted and intracellular proteins, single cell properties characterization, single cell signalling studies and even live cell imaging [8]. During the past decade, the advancement in developing instruments capable of mechanically probing and manipulating cell has reached to piconewton and nanometer scales which paved the way possible for SCA. By adopting SCA, the research systematically defined cell to cell interaction and variation, state of the cell and even addressing the heterogeneity of any cell yielding towards a more accurate and reliable results. For single cell's stiffness measurements, wide varieties of available instruments have been developed as given in Figure 1.

\section{Single cell stiffness characterization techniques Traditional}

Atomic Force Microscopy (AFM) Probing cells mechanically can be broadly categorized to how does the probing tip made contact with the cell. AFM, founded back in 1986 by Binnig et al., a technique uses the tip located at the free end of a flexible cantilever generates local deformation on the cell surface (Figure 2A). The AFM itself has undergone much development ranging from the way it operates, type of cantilever used and its applications. Depending on the region of interest, the various form of AFM tip is able to provide specific binding during indentation as to produce the Young's Modulus (E) information on elasticity. Normally, the resultant curves will depict the relationship linking force and displacement while the parameter for Young Modulus (E) can be derived from the governed equation like Hertz model [9]. AFM is suitable to be applied to living eukaryotic cells since it is non destructive and repeatable. Apart from that, the delicate topography of cells is further assessable with the help of high resolution imaging [10].
Moreover, previous works on the usage of AFM yields information on the integrity and local nanomechanical properties of mammalians cells, microbial cellular membranes [11], polymeric capsules [12] and even yeast [13] proved the AFM is practical within natural aqueous environment. As the AFM propose an active force clamp mechanism, the limitations of this technique were attributed from random positioning, difficult handling, operator dependent, big and bulky experiment set-up, random attachment and it is not suitable for non adherent cells. The application of AFM also depends on some physical cues such as the AFM tip geometry, the indenting force and operating temperature.

\section{Magnetic Twisting Cytometry (MTC)}

MTC technique applies exclusive function of magnetic beads for attachment and impose magnetic field as a twisting moment on the portion of cell (Figure 2B). By translating or twisting the external magnetic field, the applied forces and torques could be determined. Therefore, allowing determination of appropriate deformation information such as elastic or viscoelastic of the cell as the beads travels across the cell. Furthermore, tracking of beads helps for local strains derivations making the measurements of local properties of stretched cells are attainable. Experiments done by Stamenović et al. utilized MTC to determine the shear stiffness for cytoskeleton in order to prove the feasibility of cortical membrane model and tensegrity model [14]. This method generally is non invasive, versatile and clean for cell. Early research conducted by Wang et al. employing MTC to investigate mechanotransduction on the cell surface and through the cytoskeleton [15]. While Maksym et al. uses MTC to report on mechanical properties of human airway smooth muscle cells [16]. On the contrary, even the use of magnetic beads sounds convincing but it still experiences problems related to size of suitable beads and scaling of magnetic force. Moreover, common disadvantages that impede the MTC performance are low throughput and slow testing speed.

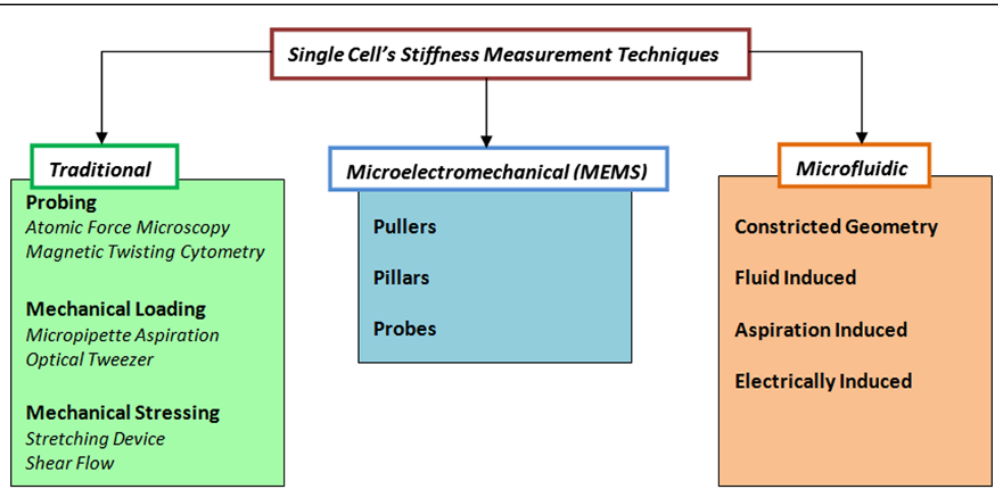

Figure 1 Various techniques for single cell's stiffness measurements. 


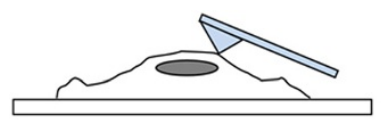

A

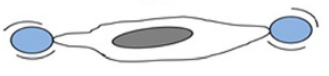

D

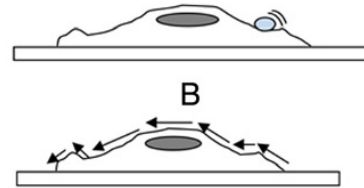

$\mathrm{E}$

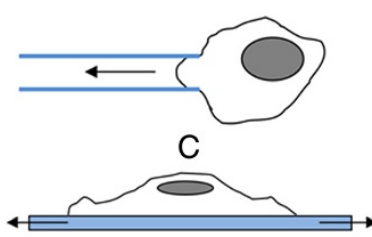

F

Figure 2 Traditional experimental approaches (A) Atomic Force Microscopy (B) Magnetic Twisting Cytometry (C) Micropipette Aspiration (D) Optical Tweezers (E) Shear Flow (F) Stretching Device.

To certain extent, some might consider MTC as a variation of magnetic tweezers and even magnetic bead microrheometry. A good example on microrheometry was the early work by Bausch et al. which explained on viscoelastic properties of adhered fibroblasts [17]. Later work by Tseng et al. introduced multiple particle tracking microrheology (MPTM) for investigation of mechanical properties of Swiss 3 T3 fibroblasts [18].

\section{Micropipette Aspiration (MA)}

The second traditional approach offers mechanical loading of an entire cell observing a massive deformation happens to cell of interest into the orifice of a glass. This is a classical technique to measure stiffness of single cells when a cell is aspirated by a small negative pressure into a glass pipette with inner diameter smaller than the cell and causing it to deform (Figure 2C). Cell elongation or geometric changes of the cell is interpreted into Young's Modulus while ignoring the friction between the cell membrane and the micropipette [19]. Several intrinsic parameters can be used to derive mechanical properties of aspirated cells for example by measuring suction pressure, cortical tension, internal viscosity, diameter of pipette orifice, cell's size and protrusion length of cell in the micropipette. The applications of MA have been tested on numerous types of cells such as HeLa, neutrophils, leukocytes, red blood cells, cancer cells and malaria infected cells [20,21]. Whilst Hochmuth et al. able to produce Young's Modulus of chondrocytes and endothelial cells, Byfield et al. showed the relationship among membrane stiffness and cholesterol for endothelial cells [21,22]. Although MA is conceptually straightforward, challenges remain in terms of specialized equipments and delicate procedures involved which requires highly skilled operator. To produce precise negative pressure is another hurdle since conventional instruments are susceptible to mechanical vibration, temperature and humidity fluctuations as well as noise offsets. Fluid loss due to evaporation may affect the sample since MA works in an open environment also need for periodic recalibration to eliminate the effect of drifting baseline.

\section{Optical Tweezers (OT)}

The other technique named as optical tweezers (OT) or sometimes is called as laser trap. Principally, two-beam laser trap is formed to serially deform single suspended cells by optically induced surface forces to measure mechanical properties of cells (Figure 2D). It relies on the theory of conservation of photon momentum. Technically, dielectric beads are placed on both sides of each cell. One is attached to the glass slide while the other is controlled by laser beam. Forces applied to the beads resultant from photon density gradient produced from laser beam generate forces up to few hundred piconewtons sufficient to deform single cell. Using OT, Brandao et al. studied the effect of drug response in terms of red blood cell elasticity for sickle cell anaemia disease [23]. Later in 2005, Mills et al. demonstrate the reproducible force - extension curves providing critical quantitative insights into the effects of parasite maturation inside the cell on the elastic and viscoelastic responses [24]. Among advantages of OT include; the ability to impose simple and well controlled stress states, it surpassed the contact problem, free from contaminants and provides high accuracy in force measurement. Certainly, the nonlinear and non-uniform stress distributions that arise due to the point loading OT represent a current challenge in the calculation of mechanical parameters. Moreover, typical OT device only capable in handling one or few cells simultaneously. In addition, the cell might suffer from heating or thermal damage due to prolong exposure. A variation of OT is called as optical stretcher eliminates the need for "handles" beads to grip the cell while affords for greater stretching force [25]. Two lasers are shone on diametrically opposite portions of the cell, but are not focused on this plane. This unfocused state reduces the intensity transmitted to the cell to obstruct any cell damage.

\section{Mechanical stressing}

The technique enables simultaneous mechanical stressing of a population of cells for instance; the shear flow method or stretching devices (Figure 2E-F). Usually, the experiments are conducted with either a cone or plate viscometer consisting of stationary flat plate in which a 
laminar flow can be exerted on it [26]. But this approach relies heavily on the type of substrate to be used as well as the compliant cell. Therefore, substrate manipulation studies are peculiar to the cell of interest as reported previously. This in vitro approach has been adapted by Wang et al. in 1995 in an attempt to impose cyclic deformation representative of in vivo conditions for melanocytes. In 2003, Pfister et al. investigated the stretch injury for neuron cell. By having in vitro setting, the effects of mechanical loading on cell morphology, phenotypes and injury were examined [27]. Different uniaxial, biaxial and pressure controlled elastic membrane stretching devices have been used to deform cells. Previous researches created potential investigations relating forces applied by cell to substrate [28-30], the assembly of focal adhesions and the contractile forces with respect to locomotion or cell migration [31-33]. Furthermore, this technique also offers alternative means to provide mechanical stimuli using substrate composition [34]. In fact, various manipulations mentioned above were achieved by controlling the chemical compositions of the substrate material or cross linking substance. While this technique affecting the mechanical properties of the substrate, nevertheless it is also important to sustain the same chemical environment of the cell population for example species, hydration and adhesivity.

\section{Microelectromechanical System (MEMS) \\ Puller}

MEMS puller normally consists of a platform, splitter and probe station (Figure 3A). A single cell is allowed to adhere across the platform, and the other half of platform will be pulled away until complete separation is achieved [35]. Series of compliant beams act as load sensors are linked to the substrate producing deflection which used to compute the applied force. While the use of optical measurements adds on complexity and introduce several limitations, usage of capacitive load sensor could be an alternative approach. The uniaxial puller designed by Serrel et al. investigated on tensile loading optimization to adherent fibroblasts cells. However, the use of fibronectin to promote adhesion resulted in a non linear behaviour with complete loss due to separation occurred at higher forces reported elsewhere [36]. In 2006, Scuor et al. fabricated a biaxial puller as an enhancement of the above technique. Upon actuation, biaxial stress can be applied uniformly on the cell of interest as the four equally spaced MEMS platforms will be pulled away from each other on micromachined linkages. Nonetheless, the preamble of this device eliminates the need for external actuator which further reduces the cost and complexity of measurements [37].

\section{Pillar}

Research on MEMS pillars were extensively done in the early of year 2000. Concept of MEMS pillars, proposes simpler experimental approach to quantify the exerted force by a cell. As the name suggests, MEMS pillars consists of an arrays or bed of closely spaced compliant pillars made from silicon or polymer (Figure 3B). Traction forces can be determined via optical microscopy resulting from deflection of pillars whenever contacts were made with cells and substrates [35]. Each pillar yielded an independent force vector favourable for subcellular traction force mapping and stiffness of each pillar can be varied through geometry of the pillars and substrate. An array of microfabricated elastometric needles reported on subcellular traction force surface mapping based on deflection of each micropost. Previous works adapting this device for study of cells interactions with substrate were conducted by $[38,39]$. Work by Tan et al. investigated on adhesion control to the pillars, relationship between cell morphology and traction forces coating effects to promote adhesion at the top of pillars [40]. Moreover, a selective functionality of micropillars using microcontact printing was also being discussed in details [41-43]. Work by Sniadecki et al. further manifested the micropillars by adding cobalt nanowires which was excited externally by an applied magnetic field [30]. With this added actuation mechanism, thereby allowing for active control over pillars. Most importantly, this device is able to measure local substrate stiffness but in contrary the accuracy is mainly contributed from the accuracy of pillar stiffness estimation (calibration) and the limitation from optical displacement resolution still hindering its performance. The common problem of cell spreading between pillars also caused the force-deflection relationship of calibrated pillar to be no longer well defined. Former version of micropillars arrays was developed by Galbraith and Sheetz used the concept of traction pads in order to check the forces tractions by fibroblasts as it moves along an axis [44]. However, it is still hard to

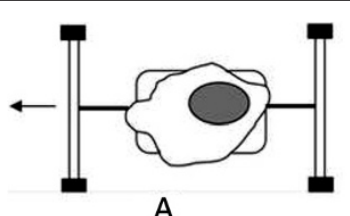

A

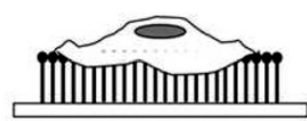

B

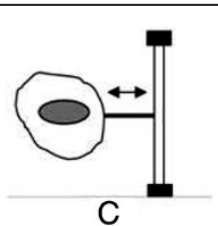

Figure 3 MEMS techniques (A) Puller (B) Pillar (C) Probes. 
precisely quantify the forces generated neither by cell nor the force distribution map due to morphological reasons; cells are active while cytoskeletal structures are dynamics.

\section{Probes}

Whereas, the application of MEMS probes are known to be superior in characterizing local force response of any interested cell (Figure 3C). Being divided into two major groups, one dimensional (1D) and two dimensional (2D) cell probes have been used in the past in order to determine mechanical properties of single cell. The device as reported by Yang and Saif consists of a suspended probe of a pairs of compliant beam of known stiffness. As the piezoelectric actuator approaches the cell, the deflections of the beams were observed. Later, the applied force is calculated using the spring constant of the beams $[45,46]$. This technique can be further improved with a coat of fibronectin to promote adhesion permits the observation of cell stretching [46]. Retrospectively, it is obvious that MEMS probes surpass the traditional AFM method in terms of reduced complexity and operates at lower cost although this technique bound to the uncertainties produced from the beam spring constant calibration. Some researchers proved that the applications towards investigation of cell morphology with respect to mechanical perturbations were made possible [35].

\section{Microfluidic}

\section{Constricted geometry}

Advances in microfabrication enable the fabrication of structures on the microfluidic platform to be used for deformation studies on single cell (Figure 4A). Various forms of customized structures for example wedge/funnel shape, vertical gap, long channel, hyperbolic shape and cross road allows for single cell deformability measurement along with parameters to characterized intrinsic cell properties. Herricks et al. developed a wedge shape capillary microchannel to study the deformability limit of RBC parasitized by Plasmodium Falciparum in a cell culture [47]. On the contrary, this work solely depends on cell geometry neglecting the effect of cell viscosity and membrane rigidity. Similar research conducted earlier by Gifford et al. in 2003 and 2006 relate the loss of haemoglobin $(\mathrm{Hb})$ and the area towards the RBC lifespan [48,49]. Filtration process done by human's spleen holds the key to distinguished diseased RBC from cell population. Several past studies using micropores, unable to demonstrate truly efficient results since the devices were prone to clogging and inefficient trappings. Few works describing the important of pore shape, sizes and cell entrance were discussed by $[5,50]$. To address this issue, Bow et al. developed an array of periodic triangular pillar filters who served as deformability cytometer implementing the concept of measuring the velocity of cells travelling through the funnel obstacles $[51,52]$. Nevertheless, this work was unable to eliminate the effect of clogging after long term operation. To further mimicking the in vivo microcirculation and the role of capillaries, a number of works described the cell deformation using gap shape constrictions [53]. Squeezing zone allows for deformation have been tested on RBC [19,54], leukocytes [55], cancer [56] and osteoblasts cells [57]. Parameters like cell transit time through constrictions, transit or passage time, entrance time during squeezing and transit velocity were used for cell deformation measurements.

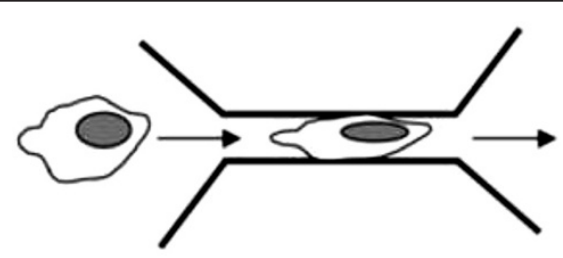

A

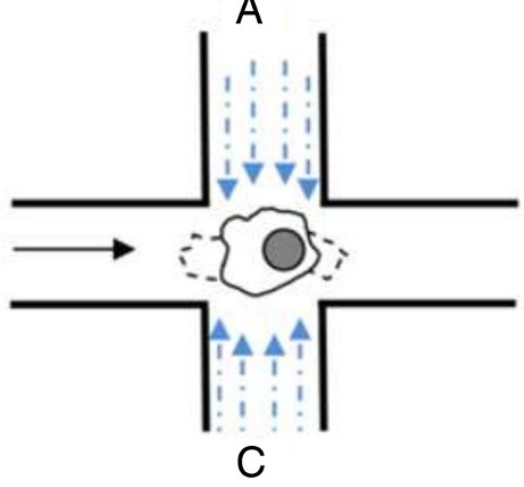

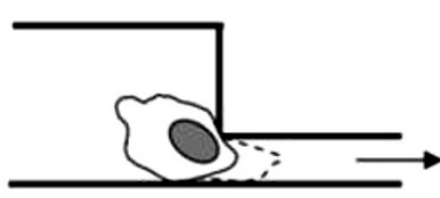

B

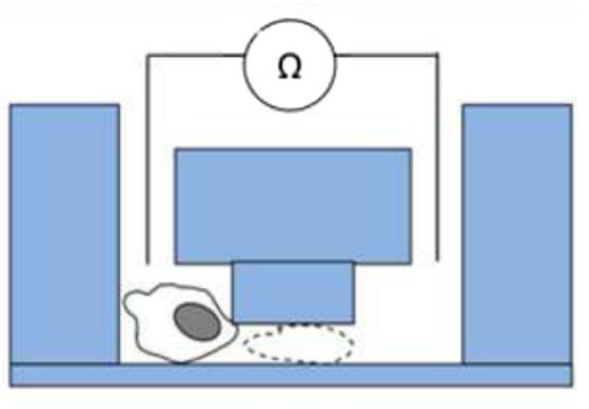

D

Figure 4 Microfluidic manipulations (A) Constricted Geometry (B) Aspiration Induced (C) Fluid Induced (D) Electrically Induced. 


\section{Aspiration induced}

This particular technique mimicked the concept of micropipette aspiration (MA) as explained previously (Figure 4B). Works on microfluidic micropipette have gained attention by researchers as there is increased interest towards rheological properties of living cells. Since the concept of MA is well translated into microfluidic, there are many previous works reported on studying of kinetic of cell shape deformation during entry, cell contour tracking [58] and nucleus deformation [59]. Works by Preira et al. in 2013 implemented successive constrictions whereby the first constriction used only to clog the leukocytes without the presence of driving fluid and the second narrower gauge was used for quantitative measurement of force, deformation, and velocity [60]. In 2012, Guo et al. proposed a ratchet mechanism to study asymmetry in the force required to deform single cells. A tapered constriction with internally regulated pressure control was tested on a range of cells include neutrophils, lymphocytes, bladder cancer and parasitized red blood cell (RBC) $[19,61]$. Kim et al. developed a microaspirator chip which able to deliver, trap and deform multiple cells while provide high throughput for HeLa cells investigation. A unique vertically raised aspiration channel design was able to eliminate the leakage problem [20]. Lateral trapping was used for micropipette array chip to measure deformation due to its simplicity, but the process is very time consuming and requires high suction pressure. Generally, by performing cell deformation measurements similar to MA using standard PDMS microchannel surely imposed several challenges due to rectangular cross section. For examples; the driving fluid might get leaked along the edges, issue on cell conformity since rounded shape of cell cannot accommodate sharp edges of PDMS channel and hard to determine shear force due to presence of additive flow in microfluidic. Nevertheless, the rectangular channels do exhibit several advantages such as ease of fabrication and easier for cell-surface observation under optical microscopy. Compared to other techniques, micropipette aspiration has a number of well established mathematical models for Young's modulus assessment.

\section{Fluid induced}

Another way to deform cell using microfluidic involves the generation of converging streamlines. This dynamic fluid equilibrium effect produces converging streamlines that able to distinguish, sort and enrich any cells in the fluidic free flow. Specifically, this technique target the cell at the center between two converging streamlines and characterized the deformation index experienced by the cell instead of direct contact with the microstructures (Figure 4C). Deformation index is defined as ratio of both axis of cross sectional area of a deformed cell has been linked with cell deformability and was proved to be an efficient biophysical marker for cell state. Works by Hur et al. demonstrated on how fluid and inertial effect can be used to further classify several types of cells and eventually helps the cell enrichment at the outlets. Cell with different elasticity and viscosity will travel separately due to different lateral dynamic equilibrium [62]. Moreover, the concept of inertial focusing can be translated further to realize hydropipetting; a combination of hydrodynamic stretching, pinched flow and extensional flow was used for high throughput application [63]. Mechanical properties resulted from this method solely rely on deformation index. On the contrary, fluid induced microfluidic proved to be appropriate for several high end applications such as focussing [64], separation [65], segregation [66], extraction [67] and filtration [68].

\section{Electrically Induced}

Mechanical manipulations involving electrically induced microfluidic has started ever since the Coulter principle was established (Figure 4D). The principle states that any particle moving through an orifice along with electric current should produce a change in impedance. By this means, the impedance changes are due to displacement of electrolytes caused by the particles movement. Vast areas emerged as a result for example electroporation, electrodeformation, electrorotation, dielectrophoresis, microelectrical impedance spectroscopy ( $\mu$-EIS) and impedance based flow Cytometry (IFC). Electroporation is referred to swelling or expansion in cell size whenever a cell experiences an externally applied electric field. Famous work by Bao et al. proved that the swelling ratio of cell caused by electroporation may reflect the malignant and metastatic status of a cancer cell [69]. It is notable that the electroporation efficiency still dependent on cell volume. Hence, the effective voltage across the cell membrane is a function of cell diameter. Therefore, cell with higher diameter when exposed to higher voltage would be easily porated. On the contrary, MacQueen et al. [70] fabricated an array of planar Ti/Pt electrodes for trapping and stimulating hamster ovary cell and human promonocyte cell. This work demonstrated the use of electrodeformation, which is defined as whenever a dielectric forces (DEP) was utilized to apply mechanical stimuli to deform a cell [71]. The Young's Modulus of cell can be determined via analytical models or numerical simulation. A single microchamber array was introduced to improve throughput of an electrodeformation device [72]. It is able to trap RBC using ITO electrodes which allow for correlation of RBC deformation with cell surface. In fact, the limitations of this method coming from time consuming procedures, limited throughput and the complex physical phenomena of unknown cell properties (varying DEP forces as a cell moves make it difficult to quantify). Electrorotation, takes place when a cell is placed in a non 
Table 1 Comparison of various techniques available for single cell's stiffness measurement

\begin{tabular}{|c|c|c|c|c|}
\hline Technique & Cell types & Advantages & Limitations & References \\
\hline \multirow[t]{3}{*}{ AFM } & \multirow{3}{*}{$\begin{array}{l}\text { Living neurons ( } 293 \text { T), biological } \\
\text { membrane, plant cell, bacteria, fungi, } \\
\text { yeast }\end{array}$} & -Wide range of applied forces & -Bulky & \multirow[t]{3}{*}[9-13]{} \\
\hline & & -Stiffness map can be generated & $\begin{array}{l}\text {-Complicated fluid-probe inter- } \\
\text { action in aqueous environment }\end{array}$ & \\
\hline & & $\begin{array}{l}\text {-Nano-indentation based on cell } \\
\text { membrane displacement }\end{array}$ & $\begin{array}{l}\text {-Difficult to be used with non } \\
\text { adherent cells }\end{array}$ & \\
\hline \multirow[t]{2}{*}{ MTC } & \multirow{2}{*}{$\begin{array}{l}\text { Mouse embryos, endothelial cells, } \\
\text { human airway smooth muscle cells, } \\
3 \text { T3 fibroblasts cells }\end{array}$} & -Non invasive & $\begin{array}{l}\text {-Special procedure to induce cell } \\
\text { binding with the beads }\end{array}$ & \multirow[t]{2}{*}{ [14-18] } \\
\hline & & -Free from contamination & $\begin{array}{l}\text {-Magnetic bead size must be large } \\
\text { enough as compared to the sample }\end{array}$ & \\
\hline \multirow[t]{6}{*}{ MA } & \multirow{6}{*}{$\begin{array}{l}\text { Neutrophils, chondrocytes, endothelial } \\
\text { cell, red blood cells (RBC), HeLa cells, } \\
\text { aortic endothelial cells }\end{array}$} & \multirow{2}{*}{$\begin{array}{l}\text {-Cell aspiration can be done without } \\
\text { cell bursting }\end{array}$} & -Slow and tedious operation & \multirow[t]{6}{*}[19-22]{} \\
\hline & & & -Need an expert for calibration & \\
\hline & & \multirow{2}{*}{$\begin{array}{l}\text {-Loading pressure can be controlled up } \\
\text { to } 0.1 \mathrm{~Pa}\end{array}$} & -Impossible for big no. of cells & \\
\hline & & & -Fluid loss due to evaporation & \\
\hline & & \multirow[t]{2}{*}{-Conceptually straightforward } & $\begin{array}{l}\text {-Susceptible to vibration, noise } \\
\text { offset and humidity }\end{array}$ & \\
\hline & & & -Time consuming & \\
\hline \multirow[t]{6}{*}{ OT } & \multirow[t]{6}{*}{ Sickle cell RBC, RBC } & $\begin{array}{l}\text {-Capable of trapping a small object } \\
\text { within a defined region }\end{array}$ & $\begin{array}{l}\text {-Forces applied is limited } \\
\text { to }<0.1 \mathrm{nN}\end{array}$ & \multirow[t]{6}{*}[23-25]{} \\
\hline & & -Surpassed the contact problem & $\begin{array}{l}\text {-Difficult handling and time } \\
\text { consuming }\end{array}$ & \\
\hline & & -Free from contaminants & $\begin{array}{l}\text {-Prone to light/optical interference } \\
\text { due to poor setting }\end{array}$ & \\
\hline & & \multirow[t]{3}{*}{-High accuracy force measurement } & -Non uniform stress distribution & \\
\hline & & & -Impossible for big no. of cells & \\
\hline & & & -Exposure to prolong heating & \\
\hline \multirow{4}{*}{$\begin{array}{l}\text { Shear/stretching } \\
\text { device }\end{array}$} & \multirow{4}{*}{$\begin{array}{l}\text { Platelets, somatic cell hybrid, astrocytes, } \\
\text { motile fish keratocyte, rat cardiac cell, } \\
\text { chick embryonic fibroblasts, NIH } 3 \text { T3 } \\
\text { cell, rat kidney epithelial cells }\end{array}$} & -Cell friendly test & \multirow{2}{*}{$\begin{array}{l}\text {-Inappropriate amount of force } \\
\text { may cause cell bursting }\end{array}$} & \multirow[t]{4}{*}{ [26-34] } \\
\hline & & -Takes place in fluid environment & & \\
\hline & & \multirow[t]{2}{*}{$\begin{array}{l}\text {-Load cells fixed to the walls of flow } \\
\text { chamber }\end{array}$} & $\begin{array}{l}\text {-Amount of force needed must be } \\
\text { made prior known }\end{array}$ & \\
\hline & & & $\begin{array}{l}\text {-Challenges to sustain similar } \\
\text { chemical environment }\end{array}$ & \\
\hline \multirow[t]{5}{*}{ MEMS - puller } & \multirow{5}{*}{$\begin{array}{l}\text { Kidney fibroblasts, BHK-21 fibroblasts, } \\
\text { adult myocytes }\end{array}$} & -No need for external actuator & -Not suitable to all types of cells & \multirow[t]{5}{*}[35-37]{} \\
\hline & & -Less cost & $\begin{array}{l}\text {-Limited to one or two degree-of- } \\
\text { freedom measurements }\end{array}$ & \\
\hline & & -Less complicated & -Not suitable to all types of cells & \\
\hline & & -High sensitivity over broad range & & \\
\hline & & -Small physical size & & \\
\hline \multirow[t]{3}{*}{ MEMS - pillar } & \multirow{3}{*}{$\begin{array}{l}\text { Epithelial cells, cardiac myocytes, } \\
\text { Bovine artery pulmonary smooth } \\
\text { muscle cells }\end{array}$} & -High sensitivity over broad range & -Cell spreading problem & \multirow[t]{3}{*}[38-44]{} \\
\hline & & -Small physical size & & \\
\hline & & -Simpler experimental set up & & \\
\hline \multirow[t]{3}{*}{ MEMS - probe } & Monkey kidney fibroblasts & -Less complexity & -Cell handling is difficult & {$[45,46]$} \\
\hline & & -Low cost & $\begin{array}{l}\text {-Need for expert personnel to } \\
\text { operate }\end{array}$ & \\
\hline & & & -Cell indentation is challenging & \\
\hline Microfluidic- & RBC, malaria infected RBC, leukaemia & -Widely used to study cell deformation & -Prone to clogging & {$[47-57]$} \\
\hline Geometry & MCF-10A cells, MCF-7 cells, MC 3 T3 & & -Inefficient trapping & \\
\hline & cells & $\begin{array}{l}\text {-Adjustable dimensions to suit different } \\
\text { cell types }\end{array}$ & $\begin{array}{l}\text {-Neglecting the effect of } \\
\text { membrane rigidity and viscosity }\end{array}$ & \\
\hline & & -Variety of geometry structure & & \\
\hline
\end{tabular}


Table 1 Comparison of various techniques available for single cell's stiffness measurement (Continued)

\begin{tabular}{|c|c|c|c|c|}
\hline \multirow{3}{*}{$\begin{array}{l}\text { Microfluidic- } \\
\text { Aspiration Induced }\end{array}$} & \multirow{3}{*}{$\begin{array}{l}\text { Porcine aortic valve interstitial line, } \\
\text { human neutrophils, mouse embryo } \\
\text { fibroblast, THP-1 cells, RBC }\end{array}$} & \multirow[t]{3}{*}{-Simple \& straightforward concept } & -Leaking problem & \multirow[t]{3}{*}[58-61]{} \\
\hline & & & -Time consuming & \\
\hline & & & -Required high suction pressure & \\
\hline \multirow[t]{5}{*}{$\begin{array}{l}\text { Microfluidic-Fluid } \\
\text { Induced }\end{array}$} & \multirow[t]{5}{*}{$\begin{array}{l}\text { HeLa cells, MCF-7 cells, RBC, leukocytes, } \\
\text { human lung H1650 cells, yeast cells, }\end{array}$} & $\begin{array}{l}\text {-Potential to process sample } \\
\text { continuously }\end{array}$ & \multirow{2}{*}{$\begin{array}{l}\text {-Taylor dispersion existence } \\
\text { making it hard to track analyte } \\
\text { concentrations }\end{array}$} & \multirow[t]{5}{*}[62-68]{} \\
\hline & & \multirow{2}{*}{$\begin{array}{l}\text {-Can be utilized with other bio- } \\
\text { chemical assays }\end{array}$} & & \\
\hline & & & \multirow[t]{3}{*}{-Limited usage for aliquoting } & \\
\hline & & -Optimized for mixing and separation & & \\
\hline & & -Deform the cell without contact & & \\
\hline \multirow[t]{5}{*}{$\begin{array}{l}\text { Microfluidic- } \\
\text { Electrically Induced }\end{array}$} & \multirow{5}{*}{$\begin{array}{l}\text { MCF-10A cells, MCF-7 cells, Chinese } \\
\text { hamster ovary cells, human } \\
\text { promonocytes cells, SiHa cells, } \\
\text { ME180 cells, RBC, DNA, L929 cells, } \\
3 \text { T3 fibroblasts cells, DS } 19 \text { murine } \\
\text { cells, bakers yeast cells }\end{array}$} & $\begin{array}{l}\text {-Faster heat dissipation, better } \\
\text { resolution, faster separation }\end{array}$ & \multirow{2}{*}{$\begin{array}{l}\text {-Streaming currents which } \\
\text { counteract with the external } \\
\text { electric }\end{array}$} & \multirow[t]{5}{*}{ [69-81] } \\
\hline & & \multirow{2}{*}{$\begin{array}{l}\text {-Enables the automation and } \\
\text { parallelization of tests with reduced } \\
\text { amount of samples }\end{array}$} & & \\
\hline & & & $\begin{array}{l}\text {-Gas bubble as a result from } \\
\text { electrolysis }\end{array}$ & \\
\hline & & \multirow[t]{2}{*}{-Enables pulse free pumping } & $\begin{array}{l}\text {-Hand-held realization is } \\
\text { challenging }\end{array}$ & \\
\hline & & & $\begin{array}{l}\text {-High energy consumption and } \\
\text { high voltage }\end{array}$ & \\
\hline
\end{tabular}

uniform electric field and the induced dipole can cause the cell to rotate (ROT). It is closely related to DEP but differs in the principle that, in DEP the cell moves but for ROT the cell will rotate. Furthermore, the ROT is more suitable for determination of intrinsic electrical properties of a single cell. More details on DEP and ROT were discussed elsewhere [73]. Dielectrophoresis is the electronic analog of optical tweezers. An electric field gradient can be created with arrangements of planar metallic electrodes either connected directly to voltage source or free floating in the presence of electric field [74]. DEP was successfully used to manipulate biological cells such as bacterial and mammalian cells $[75,76]$. Another technique called microelectrical impedance spectroscopy ( $\mu$-EIS) adopted a frequency dependent excitation signal to be applied across a trapped cell for current response measurement. Previous works on $\mu$-EIS used various types of trapping were discussed [77-79]. Famous impedance flow Cytometry is the Coulter counter. It is a widely used in clinical instruments for example the haematology analyzers. Suspended cells in a stream will be passed through electronic detection apparatus which allow for multiparametric measurements. Some detection mechanism improvements made by Gawad et al. used coplanar electrodes located in parallel allowing for differential measurements of electrical signals of RBC [80]. Latest advancement introduced by Mernier et al. demonstated the usage of liquid electrode which capable to discriminate the living and dead yeast cells and can also be used for DEP focussing of particles [81]. Eventhough this technique proven to be more powerful than Coulter counters, the establishment between cell physiological changes with their corresponding electrical properties remain vague. Therefore, making electrically induced techniques quite unpopular for cell deformation studies. This is likely due to the lack of powerful tools for cellular electrical characterization procedures. Moreover, common disadvantages suffered by all electrically induced techniques are slow throughput, complex electrical phenomena and unknown cell properties.

\section{Discussion}

The traditional approaches underlay the basic foundation offer the most straight-forward mechanisms but generally suffer from slow process, delicate procedures, low throughput, highly operator dependent and bulky experiment set-up. While shifting to a more promising direction, the emergence of MEMS and micromachining back in 1980s holds the potential to complement the existing traditional techniques available. Numerous advantages offered by MEMS, for instance capability to produce highly repeatable results with greater sensitivity, tolerable time response with low power consumption and provide excellent interface between macro scale tools and micro-nano biological systems, allows the mechanical characterization becoming more accurate. Whilst the performances of MEMS devices are comparable to traditional approaches, the suitability for cell level studies might be compromised. MEMS required continuous reliance with external actuators and sensor eventually limit the device resolution. The deployment of microfluidic devices in characterizing micro-nano biological systems open up new possibilities to researchers. Advances in mechanical characterization using microfluidic platform has intensified for the past 20 years. Since most of traditional and MEMS techniques commonly suffer from low throughput, slow operation, bulky and 
complicated experiment set up the usage of microfluidic is the ultimate solution. While most of the studies attempted proof-of-concept, the results proved to be quite significant and reliable. This technological advances capable to improve the throughput rate, requires minimum reagents, lesser costs, increased the prototyping effort, reduced complexity of experiment handling and enable the parallelization and integration between several sub-modules [82-84]. Moreover, microfluidic offers versatility during design and fabrication, portability, less laboratory space consumption, reduced risk of contamination, provide faster diagnosis, possibility for mass production and preferable for point of care (POC) device [85]. From many point of views, application of microfluidic for single cell stiffness characterization definitely overcome the limitations mentioned. As a summary, Table 1 presents the overall comparisons of various techniques available for single cell's stiffness measurement reported in the literature.

\section{Conclusion}

In this review, we summarized the single cell stiffness characterization techniques available covering from traditional approaches, MEMS based devices and the employment of microfluidic. The comparisons of benefits and limitations of each technique have been presented thoroughly. Mechanical characterizations hold the key towards understanding fundamental biophysics and also have been shown to have clinical relevance for disease diagnostics. Therefore, the potential of researchers to embark on micro total analysis system $(\mu \mathrm{TAS})$ or early disease detection are not merely an ambition. To date, various cell manipulation techniques can seamlessly be integrated into microfluidic allowing for higher degree of research. In addition, the minute scale of cells can be inherently matched with microfluidic size making it relevance for cellular studies. Along with the advancement in the microfabrication, more integrated and automated microfluidic can be designed. In the foreseeable future, closer correlations between biophysical and disease properties will be established allowing for more practical applications enabling more discoveries for the benefit of mankind.

\footnotetext{
Abbreviations

SCA: Single Cell Analysis; MEMS: Microelectromechanical System; RBC: Red Blood Cell; AFM: Atomic Force Microscopy; E: Young's Modulus; MTC: Magnetic Twisting Cytometry; MA: Micropipette Aspiration; OT: Optical Tweezer; 1D: One Dimensional; 2D: Two Dimensional; Hb: Haemoglobin; PDMS: Polydimethylsiloxane; $\mu$-EIS: Microelectrical Impedance Spectroscopy; IFC: Impedance based Flow Cytometry; Ti/Pt: Titanium/Platinum; DEP: Dielectrophoretic Force; ITO: Indium Tin Oxide; ROT: Electrorotation Force; POC: Point of Care; $\mu$ TAS: Micro Total Analysis System.
}

\section{Competing interests}

The authors declare that they have no competing interests.

\section{Authors' contributions}

ILA carried out the research works and wrote the manuscript. MR supervised the research. Final manuscript has been read and approved by both of the authors.

\section{Authors' information}

Ida Laila Ahmad received her B.Eng majoring in Electronic Engineering from Multimedia University (MMU) Cyberjaya, Malaysia in 2004. Later, in 2006 she obtained her M.Eng degree in Electrical Engineering from the Universiti

Teknologi Malaysia (UTM),Malaysia. She was appointed as the lecturer at the Electronic Department, Faculty of Electrical and Electronic Engineering, Universiti Tun Hussein Onn Malaysia (UTHM), Johor,Malaysia since 2006. Currently, she is pursuing her Ph.D in the area of single cell's stiffness characterization. Her research interests ranging from bio-electronic sensors, microfluidic detection of single cell and nanoelectronic.

Mohd Ridzuan Ahmad received the B.Eng. and M.Eng. degrees in electrical engineering from Universiti Teknologi Malaysia (UTM), Johor, Malaysia, in 2000 and 2004, respectively, and the Ph.D. degree in micro-nano systems engineering from Nagoya University, Nagoya, Japan, in 2010. From May 2000 to December 2001, he received a National Science Fellowship from the Ministry of Science, Technology and Environment, Malaysia. From June to November 2002, he was a Research Officer in the Department of Robotics and Mechatronics, UTM. Since 2003, he has been a Lecturer in the Department of Robotics and Mechatronics, Faculty of Electrical Engineering, UTM, where since 2011 he has also been a Principle Researcher at the Institute of Ibnu Sina, UTM. His research interests include multiagent robotics system, micro/ nanomanipulation, nanobiology, biomechanics, and nanodevices.

\section{Acknowledgment}

The authors would like to thank Universiti Teknologi Malaysia (UTM), Universiti Tun Hussein Onn Malaysia (UTHM) and Ministry of Education Malaysia for research and financial support. The research was funded by PRGS Grant: PRGS/1/2014/SG05/UTM/02/2.

\section{Author details}

${ }^{1}$ Faculty of Electrical and Electronic Engineering, Universiti Tun Hussein Onn Malaysia, 86400 Batu Pahat, Johor, Malaysia. '2Faculty of Electrical Engineering, Universiti Teknologi Malaysia, 81310 UTM Skudai, Johor, Malaysia.

Received: 17 July 2014 Accepted: 6 October 2014

Published online: 22 October 2014

\section{References}

1. Bao G, Suresh S (2003) Cell and molecular mechanics of biological materials. Nat Mater 2(11):715-725

2. Schoen I, Pruitt BL, Vogel V (2013) The Yin-Yang of rigidity sensing: how forces and mechanical properties regulate the cellular response to materials. Annu Rev Mater Res 43:589-618

3. Fung YC (1993) Biomechanics: mechanical properties of living tissues, vol. 9. Springer, Springer Verlag, New York p 788

4. Morrison B, Saatman KE, Meaney DF, Mclntosh TK (1998) In vitro central nervous system models of mechanically induced trauma: a review. J Neurotrauma 15(11):911-928

5. Shelby JP, White J, Ganesan K, Rathod PK, Chiu DT (2003) A microfluidic model for single-cell capillary obstruction by Plasmodium falciparuminfected erythrocytes. Proc Natl Acad Sci U S A 100(25):14618-14622

6. Byun S, Son S, Amodei D, Cermak N, Shaw J, Kang JH, Hecht VC, Winslow MM, Jacks T, Mallick P, Manalis SR (2013) Characterizing deformability and surface friction of cancer cells. Proc Natl Acad Sci U S A 110(19):7580-7585

7. Lee GYH, Lim CT (2007) Biomechanics approaches to studying human diseases. Trends Biotechnol 25(3):111-118

8. Lecault V, White AK, Singhal A, Hansen CL (2012) Microfluidic single cell analysis: from promise to practice. Curr Opin Chem Biol 16(3-4):381-390

9. Roduit C, Sekatski S, Dietler G, Catsicas S, Lafont F, Kasas S (2009) Stiffness tomography by atomic force microscopy. Biophys J 97(2):674-677

10. Sirghi L, Nakagiri N, Sugisaki K, Sugimura H, Takai O (2000) Effect of sample topography on adhesive force in atomic force spectroscopy measurements in air. Langmuir 16(20):7796-7800

11. Engel A, Müller DJ (2000) Observing single biomolecules at work with the atomic force microscope. Nat Struct Biol 7(9):715-718 
12. Vella D, Ajdari A, Vaziri A, Boudaoud A (2012) The indentation of pressurized elastic shells: from polymeric capsules to yeast cells. J R Soc Interface 9(68):448-455

13. Pelling AE, Sehati S, Gralla EB, Valentine JS, Gimzewski JK (2004) Local nanomechanical motion of the cell wall of Saccharomyces cerevisiae. Science 305(5687):1147-1150

14. Wang N, Stamenović D (2000) Contribution of intermediate filaments to cell stiffness, stiffening, and growth. Am J Physiol Cell Physiol 279(1):C188-C194

15. Wang N, Butler JP, Ingber DE (1993) Mechanotransduction across the cell surface and through the cytoskeleton. Science 260(5111):1124-1127

16. Maksym GN, Fabry B, Butler JP, Navajas D, Tschumperlin DJ, Laporte JD, Fredberg JJ (2000) Mechanical properties of cultured human airway smooth muscle cells from 0.05 to $0.4 \mathrm{~Hz}$. J Appl Physiol 89(4):1619-1632

17. Bausch AR, Ziemann F, Boulbitch AA, Jacobson K, Sackmann E (1998) Local measurements of viscoelastic parameters of adherent cell surfaces by magnetic bead microrheometry. Biophys J 75(4):2038-2049

18. Tseng Y, Kole TP, Wirtz D (2002) Micromechanical mapping of live cells by multiple-particle-tracking microrheology. Biophys J 83(6):3162-3176

19. Hochmuth RM (2000) Micropipette aspiration of living cells. J Biomech 33(1):15-22

20. Guo Q, Park S, Ma H (2012) Microfluidic micropipette aspiration for measuring the deformability of single cells. Lab Chip 12(15):2687-2695

21. Kim W (2010) A Microaspirator Chip using Vacuum Expanded Microchannels for High Throughput Mechanical Characterization of Biological Cells. Dissertation, A\&M University, Texas

22. Byfield FJ, Aranda-Espinoza H, Romanenko VG, Rothblat GH, Levitan I (2004) Cholesterol depletion increases membrane stiffness of aortic endothelial cells. Biophys J 87(5):3336-3343

23. Brandão MM, Fontes A, Barjas-Castro ML, Barbosa LC, Costa FF, Cesar CL, Saad STO (2003) Optical tweezers for measuring red blood cell elasticity: application to the study of drug response in sickle cell disease. Eur J Haematol 70:207-211

24. Mills JP, Qie L, Dao M, Lim CT, Suresh S (2004) Nonlinear elastic and viscoelastic deformation of the human red blood cell with optical tweezers. Mech Chem Biosyst 1(3):169-180

25. Van Vliet KJ, Bao G, Suresh S (2003) The biomechanics toolbox: experimental approaches for living cells and biomolecules. Acta Mater 51(19):5881-5905

26. Usami S, Chen HH, Zhao YH, Chien S, Skalak R (1993) Design and construction of a linear shear-stress flow chamber. Ann Biomed Eng 21(1):77-83

27. Pfister BJ, Weihs TP, Betenbaugh M, Bao G (2003) An in vitro uniaxial stretch model for axonal injury. Ann Biomed Eng 31:589-598

28. Ellis EF, McKinney JS, Willoughby KA, Liang S, Povlishock JT (1995) A new model for rapid stretch-induced injury of cells in culture: characterization of the model using astrocytes. J Neurotrauma 12:325-339

29. Beningo KA, Wang YL (2002) Flexible substrata for the detection of cellular traction forces. Trends Cell Biol 12(2):79-84

30. Sniadecki NJ, Chen CS (2007) Microfabricated silicone elastomeric post arrays for measuring traction forces of adherent cells. Methods Cell Biol 83:313-328

31. Pelham RJ Jr, Wang YL (1997) Cell locomotion and focal adhesions are regulated by substrate flexibility. Proc Natl Acad Sci U S A 94:13661-13665

32. Gov NS (2009) Traction forces during collective cell motion. HFSPJ 3:223-227

33. Saez A, Anon E, Ghibaudo M, du Roure O, Di Meglio J-M, Hersen P, Silberzan P, Buguin A, Ladoux B (2010) Traction forces exerted by epithelial cell sheets. J Phys Condens Matter 22:194119

34. Burton K, Taylor DL (1997) Traction forces of cytokinesis measured with optically modified elastic substrata. Nature 385(6615):450-454

35. Loh O, Vaziri A, Espinosa HD (2010) The potential of MEMS for advancing experiments and modeling in cell mechanics. Exp Mech 49(1):105-124

36. Serrell DB, Law J, Slifka AJ, Mahajan RL, Finch DS (2008) A uniaxial bioMEMS device for imaging single cell response during quantitative forcedisplacement measurements. Biomed Microdevices 10:883-889

37. Scuor N, Gallina P, Panchawagh HV, Mahajan RL, Sbaizero O, Sergo V (2006) Design of a novel MEMS platform for the biaxial stimulation of living cells. Biomed Microdevices 8:239-246

38. Zhao $Y$, Zhang $X$ (2006) Cellular mechanics study in cardiac myocytes using PDMS pillars array. Sensors Actuators A Phys 125:398-404

39. Petronis S, Gold J, Kasemo B (2003) Microfabricated force-sensitive elastic substrates for investigation of mechanical cell-substrate interactions. J Micromech Microeng 13:900-913
40. Tan JL, Tien J, Pirone DM, Gray DS, Bhadriraju K, Chen CS (2003) Cells lying on a bed of microneedles: an approach to isolate mechanical force. Proc Natl Acad Sci U S A 100(4):1484-1489

41. Xia Y, Whitesides GM (1998) Soft lithography. Annu Rev Mater Sci 28:153-184

42. Qin D, Xia Y, Whitesides GM (2010) Soft lithography for micro- and nanoscale patterning. Nat Protoc 5:491-502

43. Whitesides GM, Ostuni E, Jiang X, Ingber DE (2001) Soft lithography in biology. Annu Rev Biomed Eng 3:335-373

44. Galbraith CG, Sheetz MP (1997) A micromachined device provides a new bend on fibroblast traction forces. Proc Natl Acad Sci U S A 94:9114-9118

45. Yang S, Taher M, Saif A (2005) Micromachined force sensors for the study of cell mechanics. Rev Sci Instrum 76:044301

46. Yang S, Taher M, Saif A (2005) Reversible and repeatable linear local cell force response under large stretches. Exp Cell Res 305:42-50

47. Herricks T, Antia M, Rathod PK (2009) Deformability limits of Plasmodium falciparum-infected red blood cells. Cell Microbiol 11(9):1340-1353

48. Gifford SC, Frank MG, Derganc J, Gabel C, Austin RH, Yoshida T, Bitensky MW (2003) Parallel microchannel-based measurements of individual erythrocyte areas and volumes. Biophys J 84(1):623-633

49. Gifford SC, Derganc J, Shevkoplyas SS, Yoshida T, Bitensky MW (2006) A detailed study of time-dependent changes in human red blood cells: from reticulocyte maturation to erythrocyte senescence. Br J Haematol 135(3):395-404

50. Abkarian M, Faivre M, Stone HA (2006) High-speed microfluidic differential manometer for cellular-scale hydrodynamics. Proc Natl Acad Sci U S A 103(3):538-542

51. Bow H, Pivkin IV, Diez-Silva M, Goldfless SJ, Dao M, Niles JC, Suresh S, Han J (2011) A microfabricated deformability-based flow cytometer with application to malaria. Lab Chip 11(6):1065-1073

52. Bow HC (2010) Microfluidic devices for analysis of red blood cell mechanical properties. Dissertation, Institute of Technology, Massachusetts

53. Rosenbluth MJ, Lam WA, Fletcher DA (2008) Analyzing cell mechanics in hematologic diseases with microfluidic biophysical flow cytometry. Lab Chip 8:1062-1070

54. Forsyth AM, Wan J, Ristenpart WD, Stone HA (2010) The dynamic behavior of chemically 'stiffened' red blood cells in microchannel flows. Microvasc Res 80(1):37-43

55. Gabriele S, Versaevel M, Preira P, Théodoly O (2010) A simple microfluidic method to select, isolate, and manipulate single-cells in mechanical and biochemical assays. Lab Chip 10:1459-1467

56. Hou HW, Li QS, Lee GYH, Kumar AP, Ong CN, Lim CT (2009) Deformability study of breast cancer cells using microfluidics. Biomed Microdevices 11:557-564

57. Chen J, Zheng Y, Tan Q, Zhang YL, Li J, Geddie WR, Jewett MAS, Sun Y (2011) A microfluidic device for simultaneous electrical and mechanical measurements on single cells. Biomicrofluidics 5:14113

58. Liu X, Wang Y, Sun Y (2009) Cell Contour Tracking and Data Synchronization for real time, high accuracy micropipette aspiration. IEEE Trans Autom Sci Eng 6(3):536-543, 2009

59. Vaziri A, Kaazempur MR (2007) Mechanics and deformation of the nucleus in micropipette aspiration experiment. J Biomech 40:2053-2062

60. Preira P, Valignat M-P, Bico J, Théodoly O (2013) Single cell rheometry with a microfluidic constriction: quantitative control of friction and fluid leaks between cell and channel walls. Biomicrofluidics 7(2):24111

61. Guo Q, Reiling SJ, Rohrbach P, Ma H (2012) Microfluidic biomechanical assay for red blood cells parasitized by Plasmodium falciparum. Lab Chip 12(6):1143-1150

62. Hur SC, Henderson-MacLennan NK, McCabe ERB, Di Carlo D (2011) Deformability-based cell classification and enrichment using inertial microfluidic. Lab Chip 11(5):912-920

63. Dudani JS, Gossett DR, Tse HTK, Di Carlo D (2013) Pinched-flow hydrodynamic stretching of single-cells. Lab Chip 13(18):3728-3734

64. Hsu C-H, Di Carlo D, Chen C, Irimia D, Toner M (2008) Microvortex for focusing, guiding and sorting of particles. Lab Chip 8:2128-2134

65. Masaeli M, Sollier E, Amini H, Mao W, Camacho K, Doshi N, Mitragotri S, Alexeev A, Di Carlo D (2012) Continuous inertial focusing and separation of particles by shape. Phys Rev X 2(3):031017

66. Di Carlo D, Edd JF, Humphry KJ, Stone HA, Toner M (2009) Particle segregation and dynamics in confined flows. Phys Rev Lett 102:094503

67. Bhagat AAS, Kuntaegowdanahalli SS, Papautsky I (2008) Inertial microfluidics for continuous particle filtration and extraction. Microfluid Nanofluidics 7:217-226 
68. Bhagat AAS, Kuntaegowdanahalli SS, Papautsky I (2008) Enhanced particle filtration in straight microchannels using shear-modulated inertial migration. Phys Fluids 20:101702

69. Bao N, Zhan Y, Lu C (2008) Microfluidic electroporative flow cytometry for studying single-cell biomechanics. Anal Chem 80(20):7714-7719

70. MacQueen LA, Buschmann MD, Wertheimer MR (2010) Mechanical properties of mammalian cells in suspension measured by electro-deformation. J Micromechanics Microengineering 20(6):065007

71. Zheng $Y$, Sun $Y$ (2011) Microfluidic devices for mechanical characterisation of single cells in suspension. Micro Nano Lett 6(5):327

72. Doh I, Lee WC, Cho Y-H, Pisano AP, Kuypers FA (2012) Deformation measurement of individual cells in large populations using a single-cell microchamber array chip. Appl Phys Lett 100(2012):173702, doi: 10.1063/1.4704923

73. Morgan H, Sun T, Holmes D, Gawad S, Green NG (2007) Single cell dielectric spectroscopy. J Phys D Appl Phys 40:61-70

74. Chou C-F, Tegenfeldt JO, Bakajin O, Chan SS, Cox EC, Darnton N, Duke T, Austin RH (2002) Electrodeless dielectrophoresis of single- and doublestranded DNA. Biophys J 83:2170-2179

75. Dürr M, Kentsch J, Müller T, Schnelle T, Stelzle M (2003) Microdevices for manipulation and accumulation of micro- and nanoparticles by dielectrophoresis. Electrophoresis 24:722-731

76. Voldman J (2007) Dielectrophoretic Traps for Cell Manipulation. In: BioMEMS Biomed. Nanotechnoly, vol. IV. Springer, US, pp 159-186

77. Jang L-S, Wang M-H (2007) Microfluidic device for cell capture and impedance measurement. Biomed Microdevices 9:737-743

78. Cho Y, Kim HS, Frazier AB, Chen ZG, Shin DM, Han A (2009) Whole-Cell Impedance Analysis for Highly and Poorly Metastatic Cancer Cells. J Microelectromechanical Syst 18:808-817

79. Lan KC, Jang LS (2011) Integration of single-cell trapping and impedance measurement utilizing microwell electrodes. Biosens Bioelectron 26:2025-203

80. Gawad S, Schild L, Renaud PH (2001) Micromachined impedance spectroscopy flow cytometer for cell analysis and particle sizing. Lab Chip $1: 76-82$

81. Mernier G, Duqi E, Renaud P (2012) Characterization of a novel impedance cytometer design and its integration with lateral focusing by dielectrophoresis. Lab Chip 12:4344

82. Zare RN, Kim S (2010) Microfluidic platforms for single-cell analysis. Annu Rev Biomed Eng 12:187-201

83. Streets AM, Huang $Y$ (2013) Chip in a lab: Microfluidics for next generation life science research. Biomicrofluidics 7(1):11302

84. Breslauer DN, Lee PJ, Lee LP (2006) Microfluidics-based systems biology. Mol Biosyst 2(2):97-112

85. Rivet C, Lee H, Hirsch A, Hamilton S, Lu H (2011) Microfluidics for medical diagnostics and biosensors. Chem Eng Sci 66(7):1490-1507

\section{Submit your manuscript to a SpringerOpen ${ }^{\circ}$ journal and benefit from:}

- Convenient online submission

- Rigorous peer review

- Immediate publication on acceptance

- Open access: articles freely available online

- High visibility within the field

- Retaining the copyright to your article

Submit your next manuscript at $\gg$ springeropen.com 